\title{
Para a música é necessário paciência
}

Recebido em 16-03-2021

Aceito para publicação em 23-06-2022

\section{Bruno Cezar Malheiro}

Geógrafo, Mestre em Planejamento do Desenvolvimento pela Universidade Federal do Pará, Doutor em Geografia pela Universidade Federal Fluminense e Professor da Universidade Federal do Sul e Sudeste do Pará. E-mail: brunomalheiro84@gmail.com

Numa das manhãs ensolaradas de sábado no Rio de Janeiro, pelos corredores da feira da Praça XV: discos de vinil, roupas usadas, livros bastante antigos, pequenos objetos desgastados pelo tempo compunham um caminho em que cada artefato ganhava valor menos pela sua funcionalidade e mais pela sua capacidade de marcar histórias.

Foi pelo meio daquele mosaico de composições temporais, mais especificamente em uma das barraquinhas de vinil, que uma curta frase enunciada por um vendedor assumiu a vida necessária para se transformar em tema para esta crônica/ensaio. Disse ele:

- Para a música é necessário paciência!

Sua frase não saiu do nada, nem ecoou em tons de ensinamento. Foi mais uma dentre tantas ditas em meio a histórias contadas, palpites sobre vinis surgidos de uma profunda necessidade de conversar sobre música.

Cada disco era apresentado com sua devida explicação e ganhava contornos de personagem a contar e expressar histórias: uma versão do Brasil em três prateleiras de vinis enfileirados. Do samba à tropicália, de clube da esquina aos Novos Baianos, da Cantoria nordestina à Bossa Nova carioca, cada disco possuía uma personalidade própria: uma gravadora que o fez ou não circular, um repertório escolhido a partir de diversos critérios, um conjunto de músicos específico em cada contexto, enfim, faixas musicais que mereciam, uma a uma, preencherem de vida o nosso tempo pelas rotações da vitrola e o tocar da agulha no vinil.

Aquele vendedor fez sua vida na música, afirmou ter um grande acervo de discos em sua 
casa, mas, acima de tudo, estava ali não apenas para vender, mas para encontrar aqueles que ainda conseguem ter um apreço paciente pela música. Encontrar pessoas que ainda guardam sentidos em relação a cada composição, melodia, obra musical, parecia o ligar à vida, parecia ser uma ponte para ele se distanciar do totalitarismo da impaciência que fez surgir formas específicas de música que, em vez de preencherem de vida o tempo, preenchem de bytes uma série digital.

Nada contra a digitalização e informatização da música, mas a facilitação do acesso aos sons, ao passo que ampliou nossa capacidade de conhecer as canções produzidas em qualquer parte do mundo, pode ter nos tirado a paciência que tanto o vendedor exigiu.

Parece mesmo que perdemos a materialidade ligada à música. Poucos são aqueles que ainda a escutam pelos vinis ou mesmo pelos CDs. A cada dia que passa, montamos mais playlists e tocamos menos em qualquer objeto que nos remeta a obras musicais. Perdemos a materialidade e a memória tem deixado de ser acionada pelo toque.

As músicas são cada vez mais separadas de suas coletâneas para compor as nossas coletâneas. A capacidade de fazer sentido como obra vai sendo substituída pelo sentido da série, sua expressão única se desfaz pela impaciência perceptiva e a sua potência de fazer sentido e produzir sensações vai sendo substituída pela necessidade de compor um passa tempo sonoro, muitas vezes, esvaziado de sentido. As canções passam por nós e, quase sempre, não deixamos brecha para que elas nos toquem.

Não quero dizer com isso que não haja pessoas que continuam experimentando as músicas seja em que formato for. Mas a frase emitida pelo vendedor de disco é, na verdade, um ensinamento de que a mudança nas formas de ouvir é, também, uma mudança nas formas de percepção, de modo que o apreço e a vontade de escutar uma canção hoje vêm menos da vontade de conhecer uma obra e mais da tirania da intimidade. Tiramos qualquer marca de ritual que, por ventura, tivesse no ato de escutar uma música e jogamos tudo na fogueira da cotidianidade.

Essas parecem marcas do processo de transformação da música em mais uma mercadoria, parecem indicar que o sentido de obra é substituído pela utilidade perceptiva do consumidor individual. Nesse cenário, os ritmos são moldados, os sons compostos em harmonias moduladas pela indústria fonográfica, e a eles parece necessário o signo da instantaneidade, da obsolescência. A repetição e reprodutibilidade dos sons vai modulando nossas formas de escutar, vai impondo um padrão sonoro, empobrecendo nossa experiência musical. A puerilidade do que se escuta vai substituindo qualquer obra que queira romper com essa forma de pensar o tempo e a música no tempo e cada vez mais queremos escutar o que nossos ouvidos estão acostumados a ouvir. 
O que o vendedor reivindicava não pode ser confundido com um apresso saudosista à tradição, é apenas um alerta de que ter paciência ou mesmo a capacidade de parar e simplesmente ouvir, pode ser a melhor das armas contra a nossa, cada vez maior, pobreza de experiência. A paciência exigida às canções é um apelo contra a padronização mercantil dos nossos sentidos. 